\section{A Graft-transmissible RNA from Tomato Rootstock Changes Leaf Morphology of Potato Scion}

\author{
Hisayuki Kudo and Takeo Harada ${ }^{1}$ \\ Faculty of Agriculture and Life Science, Hirosaki University, Hirosaki \\ 036-8561, Japan
}

Additional index words. RNA, long-distance transport, phloem sap, grafting, rootstock, scion

\begin{abstract}
Heterografting experiments were conducted using potato (Solanum tuberosum) as scion and tomato (Lycopersicon esculentum) as stock to test whether an RNA molecule responsible for changing leaf shape can be transported and function across the grafting junction. Results showed that a graft-transmissible RNA from the tomato rootstock without any leaves can indeed change leaf morphology of the potato scion. Therefore, if a transgenic stock plant with acquired RNA transport competence could be constructed, it would provide an effective system for transformation of scion plants. This combination of grafting and RNA transport could provide a novel technique for cultivar improvement in horticultural crops.
\end{abstract}

In higher plants, in addition to carbohydrates, amino acids, and other nutrients, specific RNA molecules and some proteins are transported in the phloem (Wu et al., 2006). Ruiz-Medrano et al. (1999) identified several mRNA molecules in the phloem sap through the characterization of the cDNA clones obtained from pumpkin (Cucurbita maxima Duchesne) sap. Yoo et al. (2004) demonstrated the presence of an endogenous population of small RNA species, ranging from 18 to 25 nucleotides in size, in the phloem sap of pumpkin, cucumber (Cucumis sativus L.), white lupin (Lupinus albus L.), castor bean (Ricinus communis L.), and yucca (Yucca filamentosa L.). Because the sequences of these small RNAs correspond to several putative target genes, it was proposed that phloem sap contains bona fide small regulatory RNA (Eckardt, 2004; Yoo et al., 2004).

By using heterografting techniques with cucumber as scion and pumpkin as stock, Lucas's group at the University of California at Davis showed evidence of a selective system for the delivery of specific RNA molecules into developing tissues of scions through the sieve element (Haywood et al., 2002; Ruiz-Medrano et al., 1999; XoconostleCázares et al., 1999). Gómez et al. (2005) revealed that several phloem proteins having a wide RNA-binding activity are able to move through intergeneric grafts from melon (Cucumis melo L.) to pumpkin. It has long been believed that a long-distance signal, named florigen, is transported from leaves to the shoot apex (Zeevaart, 1976). Recently,

Received for publication 12 Sept. 2006. Accepted for publication 12 Oct. 2006.

This work was supported in part by the Fund for the Promotion of International Scientific Research. These experiments were carried out at the Gene Research Center of Hirosaki University.

${ }^{1}$ To whom reprint requests should be addressed; e-mail tharada@cc.hirosaki-u.ac.jp. it was suggested that Flowering Locus T (FT) mRNAs transcribed in leaves moves through the phloem to the shoot apex, where the FT protein is produced and interacts with another transcription factor (Abe et al., 2005; Blázquez, 2005; Wigge et al., 2005).

Therefore, the long-distance RNA translocation system appears to regulate the whole plant growth in response to specific environmental conditions. Kim et al. (2001) reported that a homeobox fusion transcript (Chen et al., 1997) in Mouse ear (Me) tomato (Lycopersicon esculentum Mill.) can alter the morphology of wild-type tomato grafted on $M e$. We are intrigued about the consequences of this phenomenon in horticultural crops, because most fruit trees and many vegetables are grafted (Lee, 1994). So we grafted potato (Solanum tuberosum L.) scions onto $\mathrm{Me}$ tomato rootstock to test whether the RNA molecule can move from $\mathrm{Me}$ tomato and whether it alters the potato leaf morphology. We present evidence for the existence and function of this supracellular information signal between scion and rootstock.

\section{Materials and Methods}

Plant materials. Seed of Me tomato (LA324) was obtained from C.M. Rick (University of California, Davis). Potato (cv. Kitaakari) and wild-type tomato (cv. Momotaro) were purchased from the market at Hirosaki in Japan. They were grown in an insect- and pathogen-free greenhouse at Hirosaki University.

Grafting experiments. Tomato and potato plants $\approx 8$ weeks old were used for grafting. Cleft grafting was carried out as follows: rootstocks from $\mathrm{Me}$ tomato were prepared by cutting off the shoot at $\approx 7 \mathrm{~cm}$ (below the cotyledons) leaving a stem with no leaves or lateral buds. The diameter of the cut surface was $\approx 10 \mathrm{~mm}$. A vertical cut, 1 to $2 \mathrm{~cm}$ long, was then made in the center of the stem. For the scions, apical shoots longer than $2 \mathrm{~cm}$ were prepared from potato plants, the apex was cut off, all leaves were removed at the base of the petiole to leave lateral buds, and the base of the scion was trimmed to a wedge. The wedge was inserted into the slit, and the scion/stock junction was secured with parafilm. During the first week after grafting, plants were covered with a plastic bag to avoid dehydration. Grafted plants were grown for another 3 weeks in the greenhouse at Hirosaki University before samples were taken for analysis.

Reverse transcription-polymerase chain reaction and DNA gel blot analysis. Total RNA from the sample tissues was extracted with guanidium thiocyanate followed by ultracentrifugation on a $\mathrm{CsCl}$ gradient (Wakasa et al., 2006). The RNA was amplified with a BD SMART mRNA Amplification Kit (Clontech PR37036, Mountain View, Calif.). For reverse transcription-polymerase chain reaction (RT-PCR) of PFP-T6 fusion RNA, primers described by Kim et al. (2001) were used. First-strand cDNA was synthesized with oligo-dT primer. PCR amplification with primers PFP2 and LeT6-2 was performed under the following standard conditions: $94{ }^{\circ} \mathrm{C}$ for $3 \mathrm{~min}$ followed by 40 cycles of $94{ }^{\circ} \mathrm{C}$ for $1 \mathrm{~min}, 52{ }^{\circ} \mathrm{C}$ for $2 \mathrm{~min}$, and $72{ }^{\circ} \mathrm{C}$ for $3 \mathrm{~min}$. To identify the PCR products, aliquots of the PCR products were electrophoresed on agarose gel $(2.0 \%)$, and then the separated bands were blotted on a Hybond N-Plus nylon membrane (Amersham Pharmacia Biotech, Arlington Heights, Ill.). The DNA fragment amplified from $M e$ tomato genomic DNA by using LeT6-1 and LeT6-2 primers (Kim et al., 2001) was used as the probe. The fragment was labeled with ${ }^{32} \mathrm{P}$ dCTP using a Prime-It II (Stratagene, La Jolla, Calif.) random primer labeling kit.

Isolation and RNA extraction from phloem sap. Phloem sap was collected as follows. Stems of 4-week-old Me tomato were cut with a razor blade at $\approx 7 \mathrm{~cm}$ above the ground. The first sap exudate was collected in a sterile micropipette and discarded. Subsequent exudates were collected in microtips and immediately frozen at $-80{ }^{\circ} \mathrm{C}$. The RNA fraction was isolated using TRI Reagent LS (Molecular Research Center, Cincinnati). Phloem sap $(250 \mu \mathrm{L})$ and TRI Reagent LS $(750 \mu \mathrm{L})$ were mixed and left for $5 \mathrm{~min}$ at room temperature, then chloroform $(200 \mu \mathrm{L})$ was added, and the mixture was shaken for $15 \mathrm{~s}$. The mixture was left at room temperature for $15 \mathrm{~min}$ and then centrifuged at $12000 \mathrm{rpm}$ for $15 \mathrm{~min}$. The aqueous phase was recovered, 2-propanol $(500 \mu \mathrm{L})$ was added, and then the mixture was left for $10 \mathrm{~min}$ at room temperature. The RNA was then precipitated and resuspended in RNasefree water.

\section{Results and Discussion}

Thirteen of the 20 grafted potato scions on the $\mathrm{Me}$ tomato rootstock produced leaves (Table 1, Fig. 1). All the leaves had rounded lobes, which closely resembled those of $\mathrm{Me}$ 
Table 1. Phenotypic changes seen in potato scions after grafting.

\begin{tabular}{|c|c|c|c|c|}
\hline \multirow[b]{2}{*}{ Tomato stock } & \multirow{2}{*}{$\begin{array}{l}\text { Total number } \\
\text { of scions }\end{array}$} & \multirow{2}{*}{$\begin{array}{c}\text { Number of scions with } \\
\text { new leaf growth }\end{array}$} & \multicolumn{2}{|c|}{$\begin{array}{c}\text { Number of scions with } \\
\text { leaf morphology resembling }\end{array}$} \\
\hline & & & $\overline{M e \text {-type }}$ & Potato type \\
\hline$\overline{M e}$ & 20 & 13 & 13 & 0 \\
\hline Wild-type & 2 & 2 & 0 & 2 \\
\hline
\end{tabular}

$M e=$ Mouse ear.
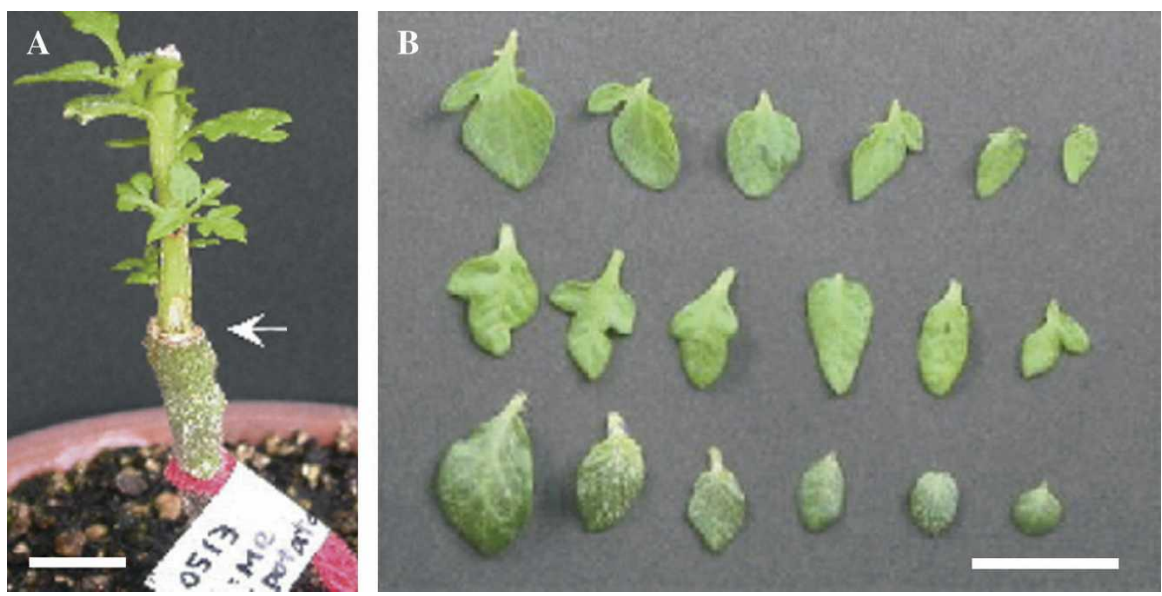

Fig. 1. Leaf morphology. (A) Leaves that developed from lateral buds of potato scion grafted on $M e$ tomato. Arrow indicates the scion/stock junction. (B) Comparison of leaf morphology. Top row, Me tomato; middle row, potato scion on Me stock; last row, potato. Leaves are of similar ages. Scale bars = $10 \mathrm{~mm} . \mathrm{Me}=$ Mouse ear.

tomato (Fig. 1B). The potato leaves also showed reduced trichome development, which is another character of $\mathrm{Me}$ (Chen et al., 1997; Kim et al., 2001). Because potato scions grafted onto wild-type tomato stock showed no changes (Table 1), the Me root system on its own therefore can alter the scion leaves.

RT-PCR and DNA gel blot analysis revealed the presence of the responsible chimeric transcript (Chen et al., 1997; Kim et al., 2001; Parnis et al., 1997)_pyrophosphate-dependent phosphofructokinase (PFP)LeT6 (KNOTTED-1-like homeobox)-in the potato scion as well as in the wild-type tomato scion (Fig. 2). Therefore, the $\mathrm{Me}$-like potato leaves appeared to have been induced by the transcript transported through the graft junction from the Me stock. Kim et al. (2001) reported that PFP mRNA moved singularly through the phloem. We also verified the presence of PFP mRNA in the sap from the Me stock by RT-PCR (data not shown).

The results indicate that the rootstock without leaves supplied enough of the chimeric transcript to alter the scion leaves. Although the PFP enzyme functions in young leaves and actively growing areas of leaves, PFP activity is ubiquitously distributed in plants (Nielsen and Stitt, 2001). The detection of PFP transcript in the sap from the cut surface also demonstrated the action of PFP promoter activity in the lower parts of the plant, mainly the root system.

Since the time of ancient Greece, grafting has been used to propagate superior clones of fruit trees. This technique has now been
Chen, J.-J., B.-J. Janssen, A. Williams, and N. Sinha. 1997. A gene fusion at a homeobox locus: Alterations in leaf shape and implications for morphological evolution. Plant Cell 9:1289-1304.

Eckardt, N.A. 2004. Small RNA on the move. Plant Cell 16:1951-1954.

Gómez, G., H. Torres, and V. Pallás. 2005. Identification of translocatable RNA-binding phloem proteins from melon, potential components of the long-distance RNA transport system. Plant J. 41:107-116.

Haywood, V., F. Kragler, and W.J. Lucas. 2002. Plasmodesmata: Pathways for protein and ribonucleoprotein signaling. Plant Cell 14:S303-S325.

Kim, M., W. Canio, S. Kessler, and N. Sinha. 2001. Developmental changes due to long-distance movement of a homeobox fusion transcript in tomato. Science 293:287-289.

Lee, J.M. 1994. Cultivation of grafted vegetables. 1. Current status, grafting methods, and benefits. HortScience 29:235-239.

Liu, Y.-S. 2006. Historical and modern genetics of plant graft hybridization. Adv. Genet. 56:101-129.

Nielsen, T.M. and M. Stitt. 2001. Tobacco transformants with strongly decreased expression of pyrophosphate: Fructose-6-phosphate expression in the base of their young growing leaves contain much higher levels of fructose-2,6bisphosphate but no major changes in fluxes. Planta 214:106-116.

Ohata, Y. 1991. Graft-transformation, the mechanism for graft-induced genetic changes in higher plants. Euphytica 55:91-99.

Parnis, A., O. Cohen, T. Gutfinger, D. Hareven, D. Zamir, and E. Lifschitz. 1997. The dominant developmental mutants of tomato, Mouseear and Curl, are associated with distinct modes of abnormal transcriptional regulation of a Knotted gene. Plant Cell 9:2143-2158.

Ruiz-Medrano, R., B. Xoconostle-Cázares, and W.J. Lucas. 1999. Phloem long-distance transport of $C m N A C P$ mRNA: Implications for supracellular regulation in plants. Development 126:4405-4419.

Taller, J., N. Yagishita, and Y. Hirata. 1999. Graft-induced variants as a source of novel characteristics in the breeding pepper (Capsicum annum L.). Euphytica 108:73-78.

Wakasa, Y., H. Kudo, R. Ishikawa, S. Akada, M. Senda, M. Niizeki, and T. Harada. 2006. Low expression of an endopolygalacturonase gene in apple fruit with long-term storage potential. Postharv. Biol. Technol. 39:193-198.

reduce infections incited by pathogens, to increase resistance to drought, and to enhance nutrient uptake. There are reports highlighting changes in characters of the scion by grafting (Ohata, 1991; Taller et al., 1999). Some of these changes might be responsible for the transport of the gene transcript (Liu, 2006). If rootstocks can be made by gene engineering to produce a desirable RNA that can alter the scion phenotype, this would create a novel system for cultivar improvement in vegetable and tree crops.

\section{Literature Cited}

Abe, M., Y. Kobayashi, S. Yamamoto, Y. Daunin, A. Yamaguchi, Y. Ikeda, H. Ichinoki, M. Notaguchi, K. Goto, and T. Araki. 2005. FD, a bZIP protein mediating signals from the floral pathway integrator FT at the shoot apex. Science 309:1052-1056.

Blázquez, M.A. 2005. The right time and place for making flowers. Science 309:1024-1025.
Wigge, P.A., M.C. Kim, K.E. Jaeger, W. Busch, M. Schmid, J.U. Lohmann, and D. Weigel. 2005. Integration of spatial and temporal information during floral induction in Arabidopsis. Science 309:1056-1059.

Wu, X., D. Weigel, and P.A. Wigge. 2006. Signaling in plants by intercellular RNA and protein movement. Genes Dev. 16:151-158.

Xoconostle-Cázares, B., Y. Xiang, R. RuizMedrano, H.-L. Wang, J. Monzer, B.-C. Yoo, K.C. McFarland, V.R. Franceschi, and W.J. Lucas. 1999. Plant paralog to viral movement protein that potentiates transport of mRNA into the phloem. Science 283:94-98.

Yoo, B.-C., F. Kragler, E. Varkonyi-Gasic, V. Haywood, S. Archer-Evans, Y.M. Lee, T.J. Lough, and W.J. Lucas. 2004. A systemic small RNA signaling system in plants. Plant Cell 16:1979-2000.

Zeevaart, J.A.D. 1976. Physiology of flower formation. Annu. Rev. Plant Physiol. 27:321-348. 